\title{
Trial of Fingolimod Versus Interferon Beta-1a in Pediatric Multiple Sclerosis
}

\author{
Pediatrik Multipl Sklerozda Fingolimod ve İnterferon Beta-1a'nın Karşılaştırılması
}

\author{
(1) Miraç Ayşen Ünsal \\ Sultan Abdulhamid Han Training and Research Hospital, Clinic of Neurology, Istanbul, Turkey
}

Keywords: Pediatric multiple sclerosis, fingolimod, interferon beta-1a

Anahtar Kelimeler: Pediatrik multipl skleroz, fingolimod, interferon beta-1a

\section{Trial of Fingolimod Versus Interferon Beta-1a in Pediatric Multiple Sclerosis}

Although multiple sclerosis (MS) typically occurs in young adulthood, approximately 3-5\% of cases may start in childhood or adolescence (1). In this age group, relapsing-remitting MS (RRMS) is usually seen (2).

Most of the injectable drugs that change the course of the disease, which are used in the first step, were approved by the European Medicines Agency in patients with MS over the age of 12 years (2). The efficacy and safety data of these treatments in pediatric patients were obtained from retrospective and openlabel studies. However, none of the treatments that affect the course of disease have been approved of patients under the age of 18 years by the United States Food and Drug Administration.

Oral fingolimod modulates the sphingosine-1-phosphate receptor on lymphocytes and neural cells. In 3 phase 3 studies with fingolimod in adult RRMS, risk of relapse and deficit with oral fingolimod $0.5 \mathrm{mg}$ treatment was found to be significantly lower than with placebo (3).

There are not enough randomized studies to evaluate the treatment of patients with MS under the age of 18 years. Chitnis et al. (4) compared fingolimod and intramuscular interferon beta-1a in pediatric patients with MS in the PARADIGMS trial, which was a randomized, double-blind, active-controlled, parallel-group study, and was published in The New England Journal of Medicine. In this study, patients aged 10 to 17 years of age were randomized 1:1: fingolimod $0.5 \mathrm{mg}$ per day ( $0.25 \mathrm{mg}$ per day for patients under $40 \mathrm{~kg}$ of body weight) and interferon beta-la $30 \mu \mathrm{g} /$ week. The primary endpoint of the study was the annual MS relapse rate.

A total of 215 patients were treated with fingolimod and a total of 108 were treated with interferon beta-1. The mean age of the patients was 15.3 years. The average number of relapses in all patients over two years was 2.4. The adjusted annual relapse rate was 0.12 with fingolimod and 0.67 with interferon beta1a (absolute difference, 0.55 relapse; relative difference, 82\%; $\mathrm{p}<0.001)$. The annual rate of T2-weighted new or enlarged lesions in cranial magnetic resonance imaging (MRI) as a secondary endpoint was 4.39 with fingolimod and was 9.27 with interferon1a with imaging (MRI), 9.27 (absolute difference, 4.88 lesions; relative difference, $53 \% ; \mathrm{p}<0.001)$. Other adverse events except relapses were reported in $88.8 \%$ of patients using fingolimod and in $95.3 \%$ of patients using interferon beta- 1 a. Severe adverse events were encountered in 18 patients $(16.8 \%)$ in the fingolimod group. These were seizures (four patients), infection (four patients), and leukopenia (two patients). Severe adverse events were encountered in $7(6.5 \%)$ patients receiving interferon beta-1a, including 2 patients with infection and one patient with supraventricular tachycardia.

In summary, in pediatric patients with RRMS, in a two-year follow-up period, there was a low relapse rate, fewer cumulative MRG lesions, but a higher incidence of serious adverse events

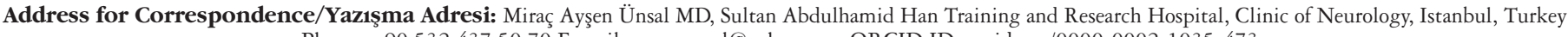
Phone: +90 5324375070 E-mail: aysenunsal@yahoo.com ORCID ID: orcid.org/0000-0002-1035-473x

Received/Geliş Tarihi: 24.12.2018 Accepted/Kabul Tarihi: 07.01.2019

${ }^{\circ}$ Copyright 2019 by Turkish Neurological Society

Turkish Journal of Neurology published by Galenos Publishing House. 
associated with fingolimod compared with interferon beta-1a. Long-term studies are needed to assess the safety and efficacy of fingolimod in pediatric patients, the open-label, five-year extension trial is still in progress.

\section{Ethics}

Informed Consent: Consent form was filled out by all participants.

Peer-review: Internally peer-reviewed.

Financial Disclosure: The author declared that this study received no financial support.

\section{References}

1. Boiko A, Vorobeychik G, Paty D, Devonshire V, Sadovnick D; University of British Columbia MS Clinic Neurologists. Early onset multiple sclerosis: a longitudinal study. Neurology 2002;59:1006-1010.

2. Jancic J, Nikolic B, Ivancevic N, et al. Multiple sclerosis in pediatrics: current concepts and treatment options. Neurol Ther 2016;5:131-143.

3. Kappos L, Radue EW, O'Connor P; FREEDOMS Study Group, et al. A placebo-controlled trial of oral fingolimod in relapsing multiple sclerosis. $\mathrm{N}$ Engl J Med 2010;362:387-401.

4. Chitnis T, Arnold DL, Banwell B; PARADIGMS Study Group, et al. Trial of Fingolimod versus Interferon Beta-1a in Pediatric Multiple Sclerosis. N Engl J Med 2018;379:1017-1027. 